\title{
Designing Model for Integrated Provincial Web Tourism Based on its Functions
}

\author{
Suroto Adi \\ School of Information System, Bina Nusantara University \\ Jl. KH. No. Syahdan. 9, Palmerah, West Jakarta 11480 \\ sadi@binus.edu,suroto@indosat.net.id
}

\begin{abstract}
Tourism product is not business of a single service but it consists of complementary products including: products of tourism, travel services and tourist hotel. Today web technology has been used for improving the promotion and marketing of the tourism products in Indonesia, but it has not complementary supported promotional and marketing activities optimally yet. This study aims to design a model of the provincial tourism office websites, travel agencies and tours, hotels, and tourist destinations in the perspective of integrated marketing and promotion, technical development, and website management involving the government through the Department of Tourism as the facilitator of business activities. The first research method used was Entity Relationship (ER) to develop a collaboration model. The second was Object Oriented Analysis Design $(O O A D)$ to analyze the information needs based on the modeling approach. The obtained model was proposed as a basis for development of the integrated website. It is hoped that the integrated webs increase promotion and marketing productivity.
\end{abstract}

Keywords: web technology, integrated web, promotion and marketing, productivity

\section{Introduction}

Tourism industry in Indonesia has attempted to improve its services. However, the results are not satisfactory yet. Data presented by Center Bureau of Statistics and ASEAN Tourism Boards [1] indicated that the number of tourist visited Indonesia below the number in other ASEAN countries. One effort carried out was the use of web technologies to support the promotion and marketing of tourism products and services implemented by tourism offices and businesses in tourism including tourism offices, travel agents, hotels, and tourist destinations.

Referring to the Government Regulation on Tourism of Indonesia [2-5], Office of Tourism functioned as a facilitator to create a comfortable climate for tourism activities undertaken by the private sectors. These activities are meant to flourish these sectors, which finally increase Indonesia national income and social welfare.

Tourism products are not the single service business, but they consist of complementary products including tourism products, product travel services and tourist hotels $[6,9,11]$. Therefore, tourism information, especially the promotion and marketing of tourism needs to be integrated in order to encourage more tourists to visit Indonesia by providing the information desired by the tourists before visiting. From the aspect of the use of information technology, especially in the use of web technology, websites in these business areas need to be integrated so that the information generated is able to support the collaboration among related field [12]. In terms of marketing, the integration needs to be carried out in various ways that are mutually supportive one another. In terms of the operation, it needs for collaboration towards the cost of operational savings and efficiency improvement. The evaluation of the four groups of tourism websites described that the 
websites were developed independently [7, 10]. Based on the previous researches, the objectives of these researches were to analyze the integration of tourism websites and to develop the appropriate models to support tourism promotion, marketing and transaction services more efficient.

\section{Methodology}

The methods used in this study were Entity Relationship (ER) and Object Oriented Analysis Design (OOAD). ER model was used to describe relationship among integrated webs, whereas OOAD was used to identify the information needs by using the business use-case and use-case analysis approaches. The study of tourism regulations in Indonesia and organization functions were conducted by the researcher to design proposed collaboration model and integrated data model. Models of business and data relationship were presented by using Use Case Diagram and Logical Class Diagram [8].

\section{Discussion}

\subsection{Collaboration Model}

Based on the organization functions, tourism actors, which consist of offices of tourism, tour and tourism travel agents, hotels, and the tourism destinations should develop collaboration by using a collaboration web [13, 14]. Figure 1 shows that they collaborate one another. In term of information system, a collaboration web means that an official tourism web will facilitate tourism actor webs by informing the promotion and marking of all tourism actors' information [15]. Furthermore, each tourism actor could inform their partner's information in their websites. 1: $\mathbf{N}$ is a relationship between Office of Tourism Webs and Hotels Webs which mean that each hotel could request to put the information regarding to promotion or marketing in the office of tourism webs and on other side, office of tourism could also request all hotel webs to display provincial tourism events.

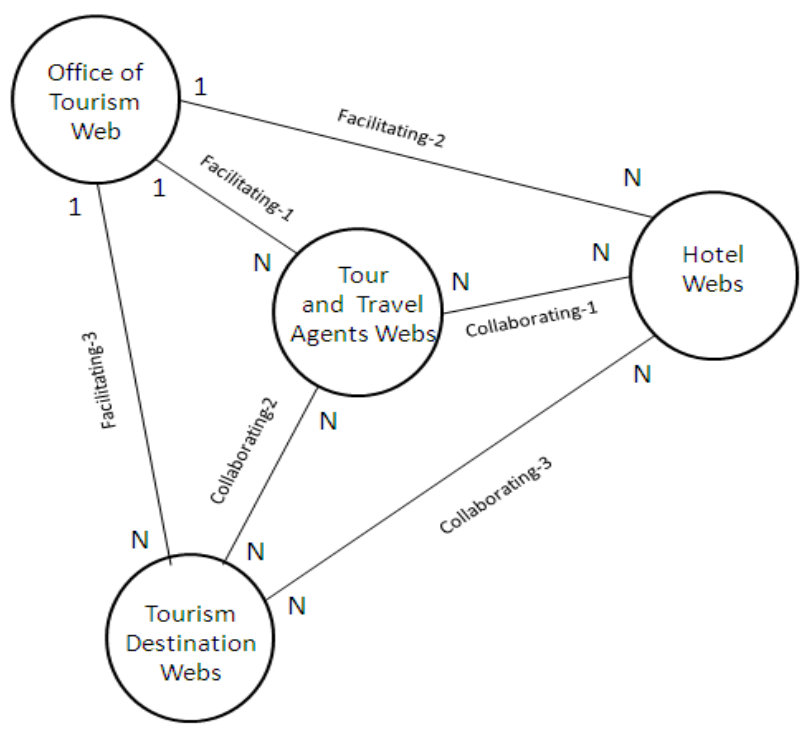

Figure 1. Provincial Web Relationship Model

$\mathbf{N}: \mathbf{N}$ is a relationship between Tour and Travel Agent Web and Hotels Web which mean that each hotel could request to put the information to be promoted or marketed in 
the office of tourism webs and on other side office of tourism could also request hotel partners' web to display their business profiles.

The benefit of this model is the availability of multiple channels, which benefit to the visitors who explore the tourism information. Selected information, which contains tourism objects, is not only available in one website, but also in many websites.

\subsection{Integrated Data Model}

In order to discuss about integrated data, the following four business use cases exhibit the role of website and the integration of selected information is presented in the partners' website and is imported from their partners. In Figure 2, Business Use-case Provincial Office Tourism Web has two main use-cases. The first accommodates the forum between the office and visitors or potential visitors. The second has three extended use-cases. They inform all short information about travel agents, hotels, and tourism destinations within the province, in which the information is imported from the original webs. For more detail information, they can go to a link facility to get the selected web.

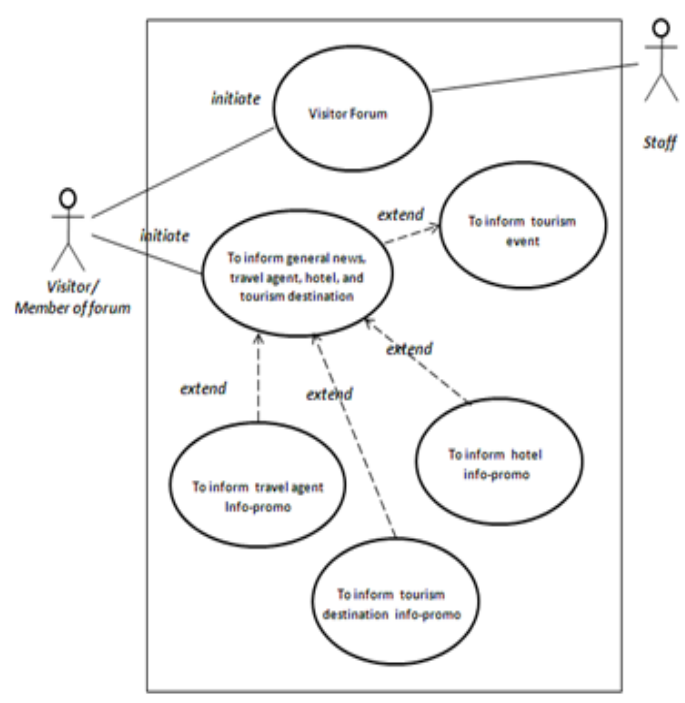

Figure 2. Business Use Case Tourism Provincial Office Web

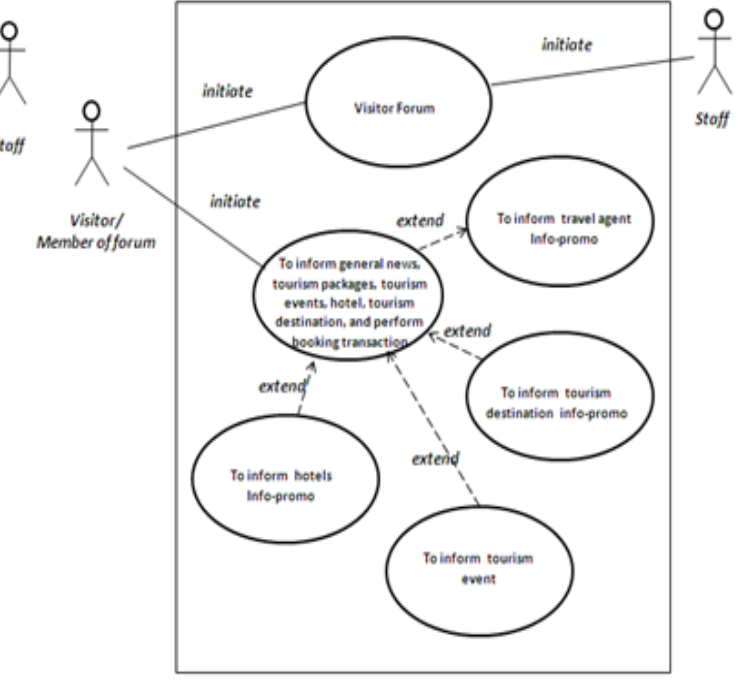

Figure 3. Business Use Case Tourism Travel Agent Web

Similar to Business Use-case Provincial Office Tourism Web, in Figure 3, Business Use-case Travel Agent Office Web has two main use-cases. These websites inform tourism packages but there are not available link features to other websites.

Business Use-case Web Hotel and Tourism, as shown in Figure 4 and 5, exhibit the role of website to support their collaboration. The hotel website informs several the nearest tourism destinations and the tourist destination informs the nearest hotel.

To see the Integrated Data Model, it is necessary to see the functions and detail descriptions of the Office of Tourism and tourism actors as shown in Table 1. There are nine proposed objects and each has attributes, which are needed by the tourism actors. 


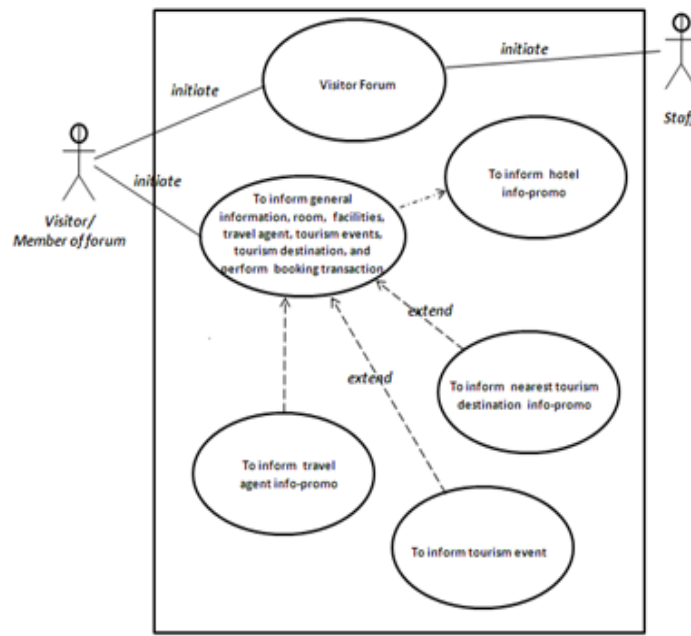

Figure 4. Business Use Case Hotel Web

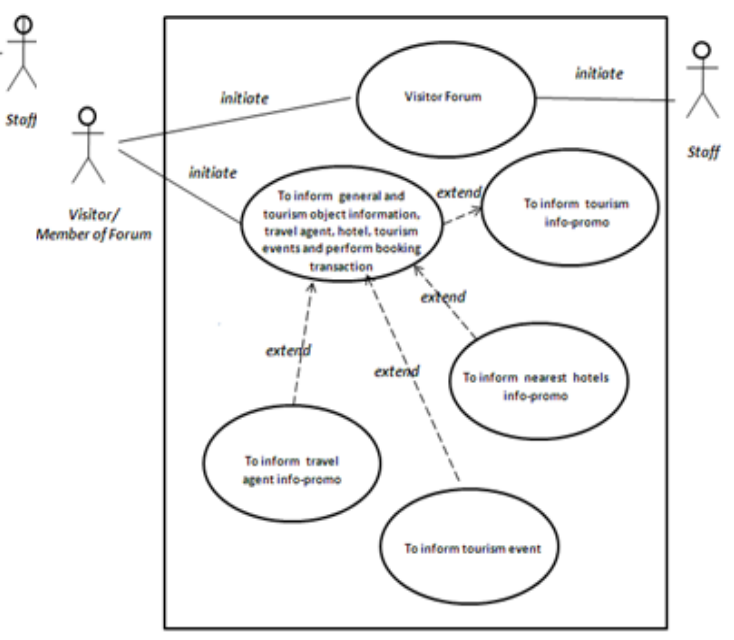

Figure 5. Business Use Case Tourism Destination Web

Table 1. General Proposed Objects and Its Attributes

\begin{tabular}{|c|c|c|}
\hline No & Proposed Objects & Attributes \\
\hline 1 & $\begin{array}{l}\text { Profile (Provincial Office of } \\
\text { Tourism, Travel Agent, Hotel, } \\
\text { Tourism Destination) }\end{array}$ & $\begin{array}{l}\text { name, logo, profile, vision, mission, address, e- } \\
\text { mail, telephone number. }\end{array}$ \\
\hline 2 & $\begin{array}{l}\text { General information (Provincial } \\
\text { Office of Tourism, Travel Agent, } \\
\text { Hotel, Tourism Destination) }\end{array}$ & general news, tourism news, weather, currency. \\
\hline 3 & $\begin{array}{l}\text { Visitors (Provincial Office of } \\
\text { Tourism, Travel Agent, Hotel, } \\
\text { Tourism Destination) }\end{array}$ & $\begin{array}{l}\text { name, account, address, e-mail, telephone } \\
\text { number. }\end{array}$ \\
\hline 4 & $\begin{array}{l}\text { Forum (Provincial Office of } \\
\text { Tourism, Travel Agent, Hotel, } \\
\text { Tourism Destination) }\end{array}$ & questions, testimonial, comments. \\
\hline 5 & $\begin{array}{l}\text { Tourism Event (Provincial Office of } \\
\text { Tourism) }\end{array}$ & $\begin{array}{l}\text { name, description of event, location, video, date } \\
\text { events. }\end{array}$ \\
\hline 6 & $\begin{array}{l}\text { Travel Agents Info-Promo (Travel } \\
\text { Agent) }\end{array}$ & $\begin{array}{l}\text { name, logo, profile, e-mail, telephone, tourism } \\
\text { packages, price. }\end{array}$ \\
\hline 7 & Hotel Info-Promo (Hotel) & $\begin{array}{l}\text { name, logo, profile, address/location, map, } \\
\text { telephone, room/price. }\end{array}$ \\
\hline 8 & $\begin{array}{l}\text { Tourism Destination Info-Promo } \\
\text { (Tourism Destination) }\end{array}$ & $\begin{array}{l}\text { name, logo, address/location, map, e-mail, } \\
\text { telephone, photos. }\end{array}$ \\
\hline 9 & $\begin{array}{l}\text { Staff (Provincial Office of Tourism, } \\
\text { Travel Agent, Hotel, Tourism } \\
\text { Destination) }\end{array}$ & name, user-name, e-mail. \\
\hline
\end{tabular}

Despite the general objects and attributes, there are possible objects or attributes to be added or eliminated in each website depending on the complexity of information needs and the process should be supported, such as booking transaction and specific tourist information. Some websites consider that information about vision, mission and strategy of the company were not important to be displayed.

The following logical class diagram, as shown in Figure 6, exhibits data relationship in more detail to accommodate all information stored in the web database. Four types of tourism web have similar database to store its data and information, even though not all file which is represented and updated by them. As an example, Office of Tourism updated 
"Tourism event" information then deliver it to other webs (Travel Agent, Hotel, Tourism Destination) while hotel update its promo then deliver to other webs (Provincial Office of Tourism, Travel Agent, Tourism Destination). It means that each actor would only update its promo and compulsory information.

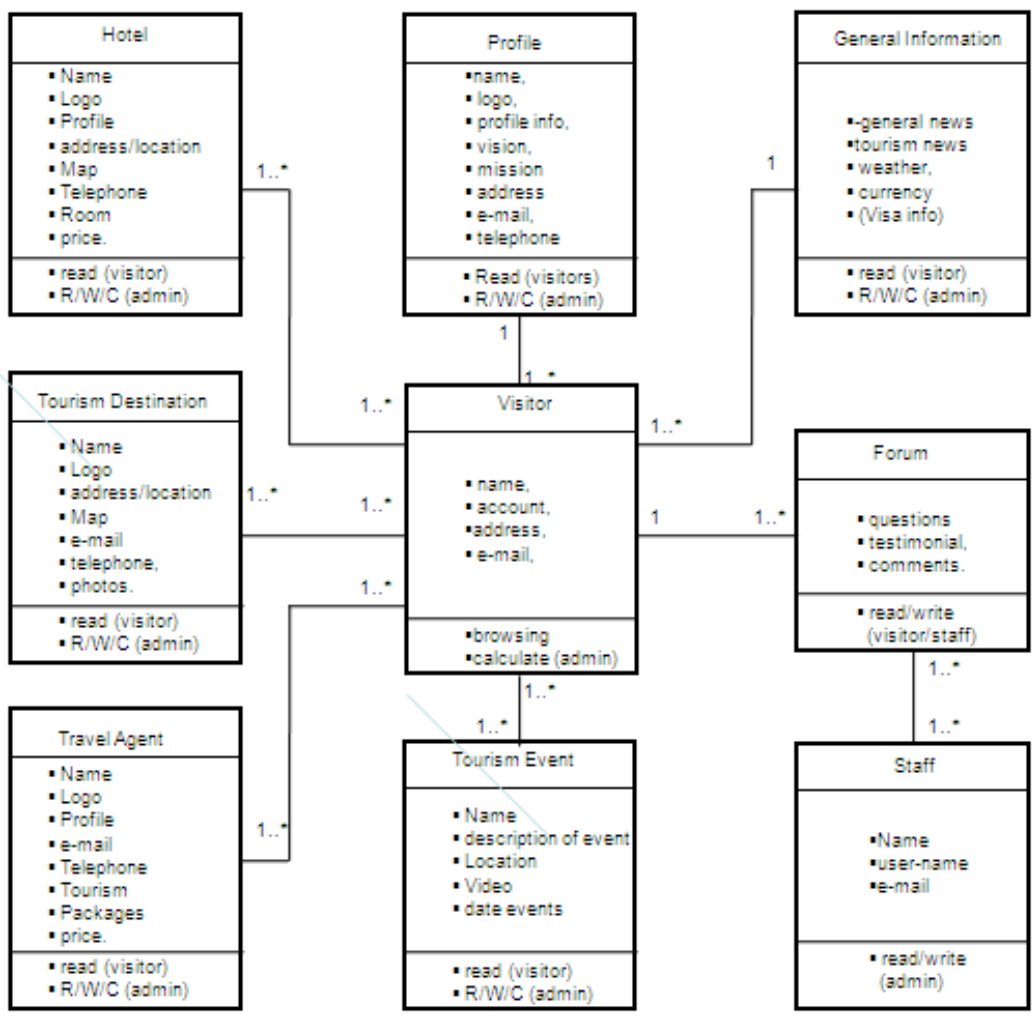

Figure 6. Logical Class Diagram

In Table 2, Data Management Responsibility exhibits the responsibility of each tourism business actor to manage its data. It exhibited that each tourism business actors develop and update its file: profile, general information, visitors, forum and staff by themselves dependently and serve the information within their websites. On the other hand, the files of tourism events, travel agents info-promo, hotel info-promo, and tourism destination info-promo were developed and updated by office of tourism, travel agents, hotel and tourism destination but they have share those information to one another.

Table 2. Data Management Responsibility

\begin{tabular}{|l|c|c|c|c|c|c|c|c|c|}
\hline $\begin{array}{c}\text { Tourism } \\
\text { Business } \\
\text { Actors }\end{array}$ & Profile & $\begin{array}{c}\text { General } \\
\text { Informa } \\
\text { tion }\end{array}$ & Visitor & Forum & $\begin{array}{c}\text { Tourism } \\
\text { Event }\end{array}$ & $\begin{array}{c}\text { Travel } \\
\text { Agents } \\
\text { Info- } \\
\text { Promo }\end{array}$ & $\begin{array}{c}\text { Hotel } \\
\text { Info- } \\
\text { Promo }\end{array}$ & $\begin{array}{c}\text { Tourism } \\
\text { Destinati } \\
\text { on Info- } \\
\text { Promo }\end{array}$ & Staff \\
\hline $\begin{array}{l}\text { Office of } \\
\text { Tourism }\end{array}$ & $\sqrt{ }$ & $\sqrt{ }$ & $\sqrt{ }$ & $\sqrt{ }$ & $\sqrt{ }$ & - & - & - & $\sqrt{ }$ \\
\hline $\begin{array}{l}\text { Travel } \\
\text { Agents }\end{array}$ & $\sqrt{ }$ & $\sqrt{ }$ & $\sqrt{ }$ & $\sqrt{ }$ & - & $\sqrt{ }$ & - & - & $\sqrt{ }$ \\
\hline
\end{tabular}




\begin{tabular}{|l|c|c|c|c|c|c|c|c|c|}
\hline Hotel & $\sqrt{ }$ & $\sqrt{ }$ & $\sqrt{ }$ & $\sqrt{ }$ & - & - & $\sqrt{ }$ & - & $\sqrt{ }$ \\
\hline $\begin{array}{l}\text { Tourism } \\
\mathrm{n}\end{array}$ & $\sqrt{ }$ & $\sqrt{ }$ & $\sqrt{ }$ & $\sqrt{ }$ & - & - & - & $\sqrt{ }$ & $\sqrt{ }$ \\
\hline
\end{tabular}

These sharing information activities become the basis of integrated web system so that update information can be real-time accessed by the users.

\section{Conclusion}

Integrated webs in the provincial level creates availability of rich information channels that it is very important to the visitors when they search tourism information and support productivity of promotion and marketing tourism business.

In line with tourism government organization functions and tourism business actors, there are hundreds of tourism websites available in provincial level that possible to be integrated by using collaboration model, as shown in Figure 1. Office of Tourism serves as facilitator and tourism business actors serve as element of collaboration among them.

The effective and efficient databases of web need to be integrated based on their common functions in spite of supports their respective specific function. The structure of database should fit not only for each member of integrated webs but also fit when they perform import and export information.

This is first step of the whole research to design provincial integrated tourism webs completely and is ready for implementation steps. Future works need to be done is designing communication model among the webs, developing prototype integrated webs and its implementation.

\section{Acknowledgements}

This research was a part of researches supported by Bina Nusantara University Jakarta under contract number 100.A/VR.RTT/VII/2014. We would like to acknowledge the Vice Rector of Research and Technology Transfer and his staffs for giving us supports in the research activities.

\section{References}

[1] Central Bureau Statistics (CBS) of Indonesia, "Statistical Yearbook of Indonesia," (2014).

[2] Ministry of Tourism of Indonesia, "The Government Regulation Number 50 Year 2011 on Tourism National Development Planning of Indonesia 2010-2025," (2011).

[3] Tourism Provincial Office of D. I. Yogyakarta, Indonesia, "The Provincial Regulation Number 1 Year 2012 on Tourism Provincial Development Planning of DI Yogyakarta 2012-2025,” (2012).

[4] Tourism Provincial Office of D.K I. Jakarta, Indonesia, "The Provincial Regulation Number 10 Year 2004 on Tourism DKI Jakarta," (2004).

[5] Tourism Provincial Office of Bali, Indonesia, "The Provincial Regulation Number 2 Year 2012 on Bali Tourism and Culture," (2012).

[6] Vellas F. and Becherel L., "The International Marketing of Travel and Tourism: A strategic Approach," Yayasan Obor Indonesia, Jakarta, (2008).

[7] Adi S., "Performance The Usage Web Technology in Indonesia Tourism by Using Modified Balanced Score Card (mBSC)," Proceedings The $2^{\text {nd }}$ International Conference on Information Systems for Business Competitiveness, Semarang Indonesia, December 5-7; (2013).

[8] J. L. Whitten, J. L., Bentley L. D., and Dittman, K. C., "System Analysis and Design Methods," 5 , McGrawHill Irwin, (2001).

[9] Ho C. L., and Lee Y. L., "The development of an e-travel service quality scale," Tourism Management, vol. 28 no. 6, (2007), pp. 1434-1449.

[10] Law R., Qi S. and Buhalis D., "Progress in tourism management: A review of website evaluation tourism research," Tourism Management, vol. 31 no.3, (2010), pp. 297-313.

[11] Getz D., "Event tourism: Definition, evolution, and research," Tourism Management, vol. 29, no. 3, (2008), pp. 403-428. 
[12] Manolis, "5 Basic Principles (\& 25 Best Practices) for DMO Websites," Http://aboutourism.wordpress.com/2010/02/01/5-basic-principles-25-best-practices-for-dmo-websites/, (2010).

[13] Ndou V. and Passiante G., "Value creation in tourism network systems," Information and Communication Technologies in Tourism", Vienna, New York, (2005), pp. 440-451.

[14] Collis T., "9 Essential Principles for Good Web Design," Http://psd.tutplus/tutorials/designingtutorials/9-essential-principles-for-good-web-design/, (2007).

[15] Buhalis D., "Progress in information technology and tourism management: 20 years on and 10 years after the Internet-The State of Tourism Research,” Tourism Management, vol. 29I no. 4, (2008), pp. 609-623.

\section{Author}

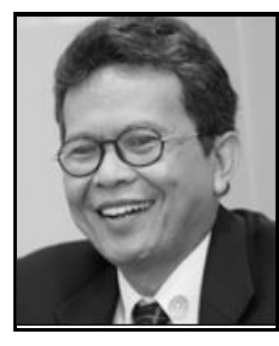

Suroto Adi, he graduated from the Faculty of Mathematics and Natural Sciences, Gadjah Mada University, Yogyakarta Indonesia. He got Master of Science degree from National Louis University (NLU), Illinois, USA and doctor of management science (DMS) from the Technological University of the Philippines (TUP), Manila, Philippines. He is former Chief of the Bureau of Information Technology Support, Chief of the Bureau of International Technical Cooperation, State Secretariat of the Republic of Indonesia. He is associate professor of Bina Nusantara University Indonesia and his interest research is IT applications in management. 
International Journal of Multimedia and Ubiquitous Engineering

Vol.10, No.6 (2015) 